\title{
Interferon-Induced, Double-Stranded RNA-Activated Protein Kinase
}

National Cancer Institute

\section{Source}

National Cancer Institute. Interferon-Induced, Double-Stranded RNA-Activated Protein

Kinase. NCI Thesaurus. Code C34095.

Interferon-induced, double-stranded RNA-activated protein kinase (551 aa, $62 \mathrm{kDa}$ ) is encoded by the human EIF2AK2 gene. This protein is involved in both serine/threonine phosphorylation and the inhibition of protein synthesis. 